\title{
Temperature influence during seed filling on tocopherol concentration in a traditional sunflower hybrid
}

\author{
By N. G. Izquierdo ${ }^{a, \S}$, S. Mascioli ${ }^{a, \S}$, L.A.N. Aguirrezábal ${ }^{a} b^{*}$ and S. M. Nolasco ${ }^{c}$ \\ a Unidad Integrada Facultad de Ciencias Agrarias, Universidad Nacional de Mar del Plata, \\ Estación Experimental Agropecuaria INTA Balcarce, C.C. 276, 7620 Balcarce, Argentina. \\ ${ }^{b}$ Consejo Nacional de Investigaciones Científicas y Técnicas (CONICET, Argentina). \\ ' Facultad de Ingeniería Química (UNCPBA). Av. Del Valle 5737, 7400, Olavarría, Argentina. \\ $\S$ These two authors have equally contributed to this work. \\ ${ }^{*}$ Corresponding author (laguirre@ @mdp.edu.ar). Unidad Integrada Facultad de Ciencias Agrarias \\ (UNMdP), Estación Experimental Agropecuaria INTA Balcarce, Ruta 226 km 73,5. C.C. 276, \\ 7620 Balcarce, Argentina. Tel: 02266-439100, fax 02266-439101.
}

\section{RESUMEN}

Efecto de la temperatura durante el llenado de las semillas sobre la concentración de tocoferoles en un híbrido tradicional de girasol.

Se investigó el efecto de la temperatura durante períodos cortos en el llenado de las semillas sobre la concentración de tocoferoles y la relación tocoferoles/ácido linoleico en un híbrido tradicional de girasol. Se realizó una siembra en campo en Balcarce el 3 y el 22 de noviembre. En cada experimento, se aplicaron tratamientos donde se incrementó la temperatura de la noche en tres períodos consecutivos de $200^{\circ} \mathrm{C}$ día (temperatura base: $6^{\circ} \mathrm{C}$ ). La concentración de tocoferoles disminuyó cuando se incrementó la temperatura de la noche temprano durante el llenado de las semillas. Dicho aumento puede ser atribuido a aumentos en la temperatura media diaria ya que no se observaron diferencias en la concentración de tocoferoles cuando se cultivaron plantas en cámaras de crecimiento con distinta temperatura nocturna y la misma temperatura media diaria. La temperatura afectó la concentración de tocoferoles principalmente al afectar el peso de aceite por semilla. La relación tocoferoles/ácido linoleico no fue afectada por la temperatura.

PALABRAS-CLAVE: Aceite - Concentración de tocoferoles - Peso por semilla - Relación tocoferoles/ácido linoleico - Temperatura.

\section{SUMMARY}

Temperature influence during seed filling on tocopherol concentration in a traditional sunflower hybrid.

The effect of night temperature during short periods in seed filling on oil tocopherol content and tocopherol/linoleic acid ratio was investigated in a traditional sunflower hybrid. Seeds were sown in the field at Balcarce on the $3^{\text {rd }}$ and $22^{\text {nd }}$ of November. In each experiment, treatments in which night temperature was increased at three consecutive periods of $200^{\circ} \mathrm{C}$ day (base temperature: $6^{\circ} \mathrm{C}$ ) were applied. Tocopherol concentration was reduced when night temperature was increased early in seed filling. Such an increase could be attributed to a correlative increase in the daily average temperature, as no differences in tocopherol concentration were found when plants were cultivated in growth chambers under different day/night temperature but at the same daily average temperature. Temperature affected tocopherol concentration mainly by affecting the oil weight per seed. The tocopherol/linoleic acid ratio was not affected by temperature.

KEY-WORDS: Oil - Temperature - Tocopherol content Tocopherol/linoleic acid ratio - Weight per seed.

\section{INTRODUCTION}

Tocopherol content influences oil quality. The antioxidant activity of tocopherols increases oil stability (Martínez de la Cuesta et al., 1995; Bramley et al., 2000). Tocopherols also play an important role as vitamin $\mathrm{E}$, which is essential for humans. This vitamin delays cellular aging (White and Xing, 1997), prevents cardiovascular diseases, causes regression of certain cancers in cell culture systems and plays an important role in the maintenance of the immune system (Devlin, 1992; Eitenmiller, 1997; Bramley et al., 2000). The requirement of tocopherol increases when the proportion of polyunsaturated fatty acids (e.g. linoleic acid in sunflower oil) in the food increases (Nagao and Yamazaki, 1983; Devlin, 1992). A requirement of $0.6 \mathrm{mg}$ tocopherol per gram of polyunsaturated acids has been suggested (American Heart Association, 2001). A high ratio is preferred because the consumption of this kind of oil reduces the fragility of the membranes of red globules, the incidence of neurological diseases (Devlin, 1992) and cardiovascular diseases, and the cellular aging produced by free radicals (Bramley et al., 2000). To obtain sunflower oil with a high tocopherol content and high tocopherol/linoleic acid ratio is important because part of the oil antioxidants is destroyed during the industry processing (Bramley et al., 2000).

The literature concerning the effect of temperature on oil tocopherol content is controversial. In field conditions, the tocopherol content in sunflower oil varied in response to planting location (Beringer and 
Dompert, 1976), or planting location and sowing date (Nagao and Yamazaki, 1983; Kandil et al., 1990), two management practices that often expose plants to different temperatures. In controlled conditions, Dompert and Beringer (1976) found that variations in the tocopherol content of sunflower plants were not explained by temperature. However, Beringer and Saxena (1968) observed that low temperatures reduced the tocopherol content in the oil of sunflower, oat and linseed plants when they were cultivated under different temperatures in growth chambers. Increasing temperature reduced the concentration of tocopherol in the oil of soybean plants grown under controlled conditions (Dolde et al., 1999) while the opposite trend has also been reported (Almonor et al., 1998). This discrepancy in the literature may occur because another factor, besides temperature, indirectly affects the tocopherol concentration in the oil. This factor could be the oil weight per seed as reported by Nolasco et al. (2004), since growth conditions during seed filling also affect the oil accumulated per seed through changes in its components, weight per seed and seed oil concentration (Dosio et al., 2000; Chimenti et al., 2001).

There are no investigations on which temperature (night, mean, etc.) mostly explains variations in tocopherol concentration. If temperature affects tocopherol content in the oil it is necessary to define which temperature (mean, minimum, night) mostly explains its variations. Night temperature and not daily mean temperature, affects the fatty acid composition of sunflower oil (Izquierdo et al., 2002). Most of the literature has mainly investigated the effect of temperature throughout the day, while the effect of night temperature on tocopherol content has never been investigated. This could be especially interesting because many studies on climate variability indicate a higher increase of minimum temperature through the years than mean or maximum temperatures (Luxmoore et al., 1997; Alward et al., 1999). Understanding whether night temperature also affects the tocopherol content and tocopherol / linoleic acid ratio could help to improve crop management in order to obtain high stability oils.

A period during which the effect of environmental factors is higher was reported for seed setting (Cantagallo et al., 1997), final weight per seed and oil concentration (Aguirrezábal et al., 2003) or final oleic acid concentration in the oil (Izquierdo et al., 2002). The effect of temperature on tocopherol content was always studied by keeping the same temperature during the entire seed filling stage and not during shorter periods. The tocopherol content of the oil could be affected by temperature during a short period in seed filling as occurs with fatty acid composition in sunflower (Izquierdo et al., 2006).

The objectives of this work were to investigate i) the effect of night temperature during short periods in seed filling on oil tocopherol content and tocopherol / linoleic acid ratio in a traditional sunflower hybrid, ii) which temperature (night, mean, etc) mostly explains the variations in tocopherol concentration and iii) if variations in tocopherol concentration originated by variations in temperature are accounted for by changes in oil weight per seed.

\section{MATERIALS AND METHODS}

\section{Field experiments}

Two experiments were conducted under field conditions at the Instituto Nacional de Tecnología Agropecuaria, Balcarce Experimental Station (37 $\mathrm{S}, 58^{\circ} \mathrm{W}$, and altitude $130 \mathrm{~m}$ ). The soil was a Typic Arguidoll (USDA taxonomy). Soil fertility and water content were not limiting for crop growth and yield (Andrade et al., 2000). Pests and diseases were adequately controlled. The flowering of a plant was registered when all florets from the capitulum outer ring showed their stamens (R5.1, Schneiter and Miller, 1981) and flowering of a plot when $95 \%$ of plants had flowers. Capitula were covered with pollination bags (Delnet, Rosario, Argentina) to prevent cross-pollination.

Seeds from Dekasol 3881, a traditional sunflower hybrid were sown on the $3^{\text {rd }}$ of November 1998 (Exp. A) and on the $22^{\text {nd }}$ of November 1998 (Exp. B). The experiment was designed as randomized complete blocks with three replicates. Plants were thinned after seedling emergence to a density of $5.3 \pm 0.3$ plants $m-2(\operatorname{Exp} . A)$ and $7.3 \pm$ 2.7 plants $\mathrm{m}-2$ (Exp. B). Flowering occurred on the $22^{\text {nd }}$ of January 1999 (Exp. A) and 5 February 1999 (Exp. B). Treatments consisted of increasing night temperature of the subplot during different periods of seed filling. Treatments were: $(\mathrm{H} 1)$ heating from 0 (flowering) to $200^{\circ} \mathrm{C}$ day after flowering (base temperature $\left.=6^{\circ} \mathrm{C}\right)$, $(\mathrm{H} 2)$ heating from 200 to $400^{\circ} \mathrm{C}$ day after flowering, (H3) heating from 400 to $600^{\circ} \mathrm{C}$ day after flowering, and (Control) no heating. Temperature was increased within enclosures of $2.6 \mathrm{~m}$ long, $1.6 \mathrm{~m}$ wide and $0.4 \mathrm{~m}$ higher than the plants, using polyethylene film (100 $\mathrm{mm}$ thickness) stretched on a pipe structure. Each enclosure contained approximately 22 plants. The roof of the enclosures covered the plants during the nightly heating period. Electrical fan heaters (2200 W) placed inside the enclosures increased air temperature from 19:00 to 6:00 h. Physiological maturity was estimated visually by the hard yellow color of the capitulum back face and by the brown color of its bracts (Farizo et al., 1982). Plants were harvested at physiological maturity (further details about both experiments in Izquierdo et al., 2002).

Air temperature was monitored in every plot and data were recorded with data loggers (Data Logger, LI-COR 1000, Lincoln, NE, USA and Delta-T DL2e Logger, Delta-T Devices Ltd. Cambridge). Mean, maximum and minimum temperatures were calculated for the whole day (from 7:00 to 6:00 h) and for the night (from 19:00 to 6:00 h). Differences in 
temperature from heated plots with respect to control plots were: $6.9^{\circ} \mathrm{C}$ for night mean temperature, $3.8^{\circ} \mathrm{C}$ for daily mean and daily minimum temperature and $0.9^{\circ} \mathrm{C}$ for daily maximum temperature (Table 1 ). Differences in temperature between heated and control plots were similar in Exp. B. Mean temperature during seed filling was $0.6 \mathrm{C}^{\circ}$ higher in Exp. B than in Exp. A (Table 1). Temperature variation obtained among treatments and experiments largely covers the variations in minimum temperature during sunflower seed filling among different regions where this species is cultivated in Argentina $\left(6.4^{\circ} \mathrm{C}\right.$ between Balcarce and P.R.S. Peña - $27^{\circ} \mathrm{S} 60^{\circ} \mathrm{W}$ ) and in a same location among different years (maximum difference $=7^{\circ} \mathrm{C}$ between 1976 and 1997 at Balcarce, Argentina). Seed temperature was measured with small thermistors $(25.00 \times 6.35 \mathrm{~mm}$, GM Electrónica, Bs As, Argentina) and data reordered with datalogers (Delta-T DL2e Logger, Delta-T Devices Ltd. Cambridge). Seed temperature followed the same trend than air temperature, with the maximum and lowest values near $15 \mathrm{hs}$ and $7 \mathrm{hs}$ respectively. Daily temperatures were similar in the seed or the air on cloudy days but it was higher in the seeds those days with high incident radiation. Night temperatures of the air or seed were similar even on cloudy or sunny days.

Treatments did not affect the plant microclimate variables other than temperature, which could also affect the tocopherol content or the fatty acid composition. The treatment application did not affect neither vapor pressure deficit nor $\mathrm{O}_{2}$ or $\mathrm{CO}_{2}$ concentration in the air (Izquierdo et al., 2002). Intercepted photosynthetic active radiation (PAR) was measured as described by Dosio et al. (2000). The amount of PAR intercepted per plant from flowering to physiological maturity did not differ among treatments $(p>0.24)$.
Ten seeds per plant obtained from a selected capitulum position (from ring 4 to ring 19 from the outer part of the capitulum to the center) were sampled every 5 days in order to investigate oil weight per seed accumulation in both experiments. Seeds were dried at $60^{\circ} \mathrm{C}$ during 48 hours and weighted and their oil concentration was determined by Nuclear Magnetic Resonance (see "sample analysis and chemical determinations"). Treatments were applied at different stages of seed oil accumulation. Figure 1 shows a typical evolution of the oil accumulation in the seeds (control treatment, Exp. A). $\mathrm{H} 1$ was applied when the amount of oil accumulated per seed was low, $\mathrm{H} 2$ during the first half of the rapid oil accumulation

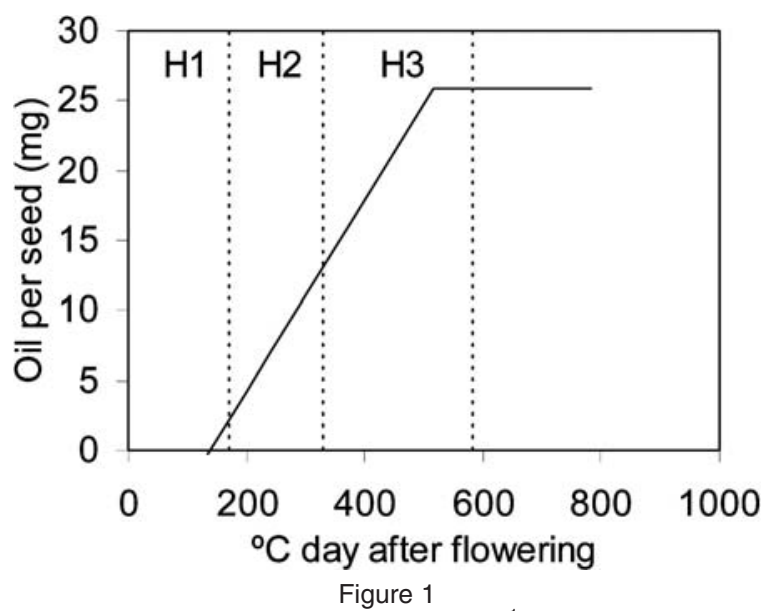

Oil accumulation in the seed $\left(\mathrm{mg} \mathrm{g} \mathrm{seed}^{-1}\right)$ as a function of $\mathrm{C}^{\circ}$ day after flowering in the traditional hybrid Dekasol 3881 and its relationship with treatment application. The line corresponds to the function adjusted to data for the control treatment of Exp. A (Izquierdo et al, 2002). Vertical lines indicate the periods when heating was applied in treatments $\mathrm{H} 1, \mathrm{H} 2$ and $\mathrm{H} 3$.

Table 1

Mean, maximum and minimum temperatures for the whole day $(24 \mathrm{~h})$ and for the heating hours (from 19:00 to 6:00 h) for control and heated plots during the period of treatment application (H1: 0-200, H2: $200-400$ and $\mathrm{H3}$ : $400-600^{\circ} \mathrm{C}$ day after flowering). Data correspond to Exp. A and B. (Izquierdo et al., 2002).

\begin{tabular}{|c|c|c|c|c|c|c|c|}
\hline \multirow{2}{*}{ Temperature } & \multirow{2}{*}{ Exp. } & \multicolumn{2}{|c|}{ H1 } & \multicolumn{2}{|c|}{$\mathrm{H} 2$} & \multicolumn{2}{|c|}{ H3 } \\
\hline & & Control & Heated plots & Control & Heated plots & Control & Heated plots \\
\hline Daily maximum & $\begin{array}{l}\text { A } \\
B\end{array}$ & $\begin{array}{l}27.1 \pm 0.6 \\
30.2 \pm 0.2\end{array}$ & $\begin{array}{l}28.4 \pm 0.9 \\
30.0 \pm 0.2\end{array}$ & $\begin{array}{l}29.5 \pm 0.4 \\
32.7 \pm 0.4\end{array}$ & $\begin{array}{l}30.2 \pm 0.3 \\
33.2 \pm 0.4\end{array}$ & $\begin{array}{l}32.9 \pm 0.2 \\
27.1 \pm 0.4\end{array}$ & $\begin{array}{l}33.7 \pm 0.4 \\
29.6 \pm 0.9\end{array}$ \\
\hline Daily mean & $\begin{array}{l}\text { A } \\
B\end{array}$ & $\begin{array}{l}19.3 \pm 0.3 \\
19.8 \pm 0.3\end{array}$ & $\begin{array}{l}23.1 \pm 0.4 \\
22.7 \pm 0.6\end{array}$ & $\begin{array}{l}19.4 \pm 0.2 \\
23.6 \pm 0.3\end{array}$ & $\begin{array}{l}23.0 \pm 0.2 \\
26.7 \pm 0.5\end{array}$ & $\begin{array}{l}23.5 \pm 0.4 \\
20.5 \pm 0.2 \\
\end{array}$ & $\begin{array}{l}27.0 \pm 0.1 \\
24.9 \pm 0.8\end{array}$ \\
\hline Daily minimum & $\begin{array}{l}\text { A } \\
B\end{array}$ & $\begin{array}{l}12.9 \pm 0.3 \\
12.0 \pm 0.2\end{array}$ & $\begin{array}{l}17.4 \pm 0.3 \\
16.5 \pm 0.4\end{array}$ & $\begin{array}{l}10.9 \pm 0.2 \\
16.9 \pm 0.2\end{array}$ & $\begin{array}{l}14.8 \pm 0.5 \\
19.8 \pm 0.3\end{array}$ & $\begin{array}{l}16.6 \pm 0.5 \\
15.3 \pm 0.3\end{array}$ & $\begin{array}{l}18.9 \pm 0.4 \\
18.7 \pm 0.3\end{array}$ \\
\hline Night maximum & $\begin{array}{l}A \\
B\end{array}$ & $\begin{array}{l}19.3 \pm 0.4 \\
18.4 \pm 0.3\end{array}$ & $\begin{array}{l}23.8 \pm 0.7 \\
22.7 \pm 1.2\end{array}$ & $\begin{array}{l}19.3 \pm 0.4 \\
22.5 \pm 0.2\end{array}$ & $\begin{array}{l}23.3 \pm 0.7 \\
27.3 \pm 1.1\end{array}$ & $\begin{array}{l}22.5 \pm 0.3 \\
19.8 \pm 0.3\end{array}$ & $\begin{array}{l}28.3 \pm 0.2 \\
26.9 \pm 1.4\end{array}$ \\
\hline Night mean & $\begin{array}{l}\text { A } \\
B\end{array}$ & $\begin{array}{l}15.3 \pm 0.4 \\
14.5 \pm 0.4\end{array}$ & $\begin{array}{l}22.0 \pm 0.6 \\
20.3 \pm 1.0\end{array}$ & $\begin{array}{l}13.9 \pm 0.3 \\
19.3 \pm 0.2\end{array}$ & $\begin{array}{l}20.6 \pm 0.6 \\
25.2 \pm 1.1\end{array}$ & $\begin{array}{l}19.0 \pm 0.3 \\
17.6 \pm 0.2\end{array}$ & $\begin{array}{l}25.8 \pm 0.1 \\
25.2 \pm 1.4\end{array}$ \\
\hline Night minimum & $\begin{array}{l}A \\
B\end{array}$ & $\begin{array}{l}13.2 \pm 0.1 \\
12.0 \pm 0.1\end{array}$ & $\begin{array}{l}18.9 \pm 0.4 \\
17.8 \pm 0.7\end{array}$ & $\begin{array}{l}10.9 \pm 0.2 \\
17.2 \pm 0.1\end{array}$ & $\begin{array}{l}18.2 \pm 0.5 \\
22.0 \pm 0.7\end{array}$ & $\begin{array}{l}16.8 \pm 0.1 \\
15.6 \pm 0.1\end{array}$ & $\begin{array}{l}22.2 \pm 0.1 \\
22.8 \pm 1.3\end{array}$ \\
\hline
\end{tabular}

Standard deviation 
phase, and $\mathrm{H} 3$ towards the end of this phase. Treatments were applied at similar stages in Exp. B (Izquierdo et al., 2002). Oil yield components, tocopherol content and linoleic acid percentage were determined in plants harvested at physiological maturity.

\section{Growth chamber experiments}

An experiment (Exp. C) with two replications was developed under controlled conditions. Seeds from Dekasol 3881 were sown on 10 I pots on the $7^{\text {th }}$ of January (Rep. 1) and on the $25^{\text {th }}$ of January (Rep. 2) 2002. After seedlings emergence 1 plant per pot was kept. Soil was fertilized with $2.6 \mathrm{~g} \mathrm{~N}$ per pot at sowing, V6 and R2 (Schneiter and Miller, 1981), and $0.35 \mathrm{~g} \mathrm{P}, 0.29 \mathrm{~g} \mathrm{~S}$ and $0.005 \mathrm{~g} \mathrm{~B}$ per pot at V4. Pots were irrigated every 12 hours to avoid water stress. Plants were kept under natural conditions at the same experimental site than Exp. A and Exp. B from sowing to treatment application. Air temperature was registered and analyzed as in field experiment and flowering of each plant was determined as described previously. Capitula were covered with self-pollination bags. Flowering (95\% of plants at R5) occurred on March 10 (Rep. 1) and April 11 (Rep. 2). Plants were exposed to three daynight temperatures: $20-28{ }^{\circ} \mathrm{C}$ (Rep. 1 and 2); 25$23^{\circ} \mathrm{C}$ (Rep. 1), and $28-20^{\circ} \mathrm{C}$ (Rep. 1 and 2) and a similar mean temperature $\left(24^{\circ} \mathrm{C}\right)$ from flowering to physiological maturity.

Temperature regimes were achieved using growth chambers (Refrimax S.R.L., Mar del Plata, Argentina) with 12-hour photoperiod and incident photosynthetic active radiation at the top of the plants of $690 \pm 75 \mu \mathrm{mol} \mathrm{m}{ }^{-2} \mathrm{~s}^{-1}$. Shorter plants were raised in order to receive the same incident radiation. Air humidity in growth chambers was measured with humidity sensors (SHW00P0420, CAREL SRL, Brugine, Italy) and chambers were calibrated to obtain the same vapor pressure deficit during the light period (30 hPa VPD). Oil yield components, tocopherol content and linoleic acid percentage were determined in plants harvested at physiological maturity.

\section{Sample analysis and chemical determinations}

Seed oil concentration was measured by Nuclear Magnetic Resonance (NMR, Analyser Magnet Type 10, Newport Oxford Instruments, Buckinghamshire, England) in duplicate and averaged. Samples were dried at $60^{\circ} \mathrm{C}$. After $18 \mathrm{~h}$, samples were located in desiccators with $\mathrm{CaO}$ until constant temperature $\left(22-24^{\circ} \mathrm{C}\right.$, Robertson and Morrison, 1979). In Exp. A treatments did not affect oil yield per plant and its components number of non-empty seeds and weight per seed $(p>0.19)$. Although $\mathrm{H} 1$ and $\mathrm{H} 2$ tend to present higher values of oil weight per seed than $\mathrm{H} 3$ and the control (Table 2), no statistically differences among treatments were observed for oil concentration and oil weight per seed $(p>0.55)$. Similar results for oil weight per seed were observed in Exp. B (Table 2).

Linoleic acid and tocopherol contents were measured in seeds from ring 4 to ring 19 of the capitulum (Izquierdo et al., 2002). Samples were obtained as a homogeneous seed mixture of all the capitula harvested in each plot or chamber. Linoleic acid percentage was determined using a gas chromatograph (GC HP 5890 gaseous-FID detector, HP-23, cis/trans FAME Column, ID 0.25 $\mathrm{mm}$, further details in Izquierdo et al., 2002). Differences among treatments were not statistically significant for linoleic acid percentage of the traditional hybrid Dekasol 3881 in Exp. A ( $p=0.31)$, however, this fatty acid tend to be lower in $\mathrm{H} 1$ than in the control $(65.4 \pm 2.5 \%$ vs $68.2 \pm 1.6 \%)$. In Exp. $\mathrm{B}, \mathrm{H} 1$ and $\mathrm{H} 2$ presented a lower linoleic acid percentage than the control $(53.0 \pm 3.6 \%$ and 46.0 $\pm 5.4 \%$ vs $59.7 \pm 5.0 \%, p=0.02$ ). Linoleic acid percentage was higher in Exp. A than in Exp. B according to the lower temperature during seed filling in this experiment (Izquierdo et al., 2002). In Exp. C, linoleic acid concentration varied from 36.9 to $49.5 \%$. Treatments with lower night temperature $\left(28-20^{\circ} \mathrm{C}\right)$ showed the higher concentration of this fatty acid. Differences among treatments were not statistically significant $(p>0.05)$.

To determine oil tocopherol content in the three experiments, seeds were ground in a mill and extracted with n-hexane (Soxhlet) 3 hours at room temperature and 3 hours at $69^{\circ} \mathrm{C}$. Solvent was evaporated in a rotary vacuum evaporator at $40^{\circ} \mathrm{C}$ and remains were extracted with $\mathrm{N}_{2}$. Tocopherol contents of crude oils were determined by normal phase HPLC using Hewlett Packard chromatography system (HP 1059 Series, Waldbronn, Germany). Approximately $0.5 \mathrm{~g}$ oil and in $5 \mathrm{~mL}$ hexane were applied to a LiChrosorb Sil $60(5 \mathrm{~mm}, 250 \mathrm{~mm} \times 4.00 \mathrm{~mm}$, Merck KgaA, Darmstadt, Germany) column. The column was eluted with n-hexane: isopropanol (99.5:0.5, 99.3:0.7, v/v, HPLC solvent, J.T. Baker, Phillpsburg, USA) at flow rate of $1.5 \mathrm{~mL} \mathrm{~min}^{-1}$. Tocopherol was detected by absorbency at $292 \mathrm{~nm}$ with an ultraviolet visible detector (HP 1050 Series) and quantified using a six-point external standard curve (A.O.C.S. 1998).

Table 2

Oil weight per seed (mg) for different night temperatures treatments from Exp. A and B.

Treatments were a control and three heating periods (H1: 0-200, H2: 200-400 and H3: $400-600{ }^{\circ} \mathrm{C}$ day after flowering). (Izquierdo et al., 2002).

\begin{tabular}{ccccc}
\hline \multirow{2}{*}{ Experiment } & \multicolumn{4}{c}{ Treatment } \\
\cline { 2 - 5 } & H1 & H2 & H3 & Control \\
\hline A & $26 \pm 5^{*}$ & $27 \pm 1$ & $24 \pm 4$ & $24 \pm 4$ \\
B & $30 \pm 6$ & $25 \pm 4$ & $23 \pm 0.2$ & $23 \pm 4$
\end{tabular}

Standard deviation 


\section{Data Analysis}

Data of oil weight per seed were adjusted to thermal time (base temperature $=6^{\circ} \mathrm{C}$ ) as Izquierdo et al. (2002). Data of tocopherol content were processed by analysis of variance procedures (General Linear Models Procedure, SAS Institute Inc. 1988). When statistical differences were detected in more than one hybrid or experiment, the highest $p$ value is presented. Differences between treatment means were evaluated using the Tukey test $(p<0.05)$. Sigma Plot software (Version 5.0, SPSS Inc. 1986-1999) was used to establish the relationships between tocopherol content and oil weight per seed. For the tocopherol/linoleic acid ratio, the amount of linoleic was calculated considering the unsaponificable fraction of the oil. As for traditional hybrids this fraction showed to be constant independently of the oil concentration and fatty acid composition (Aguirrezábal and Izquierdo, unpublished data), a mean value of 0.923 was considered for Dekasol 3881.

\section{RESULTS}

The tocopherol content in the oil ranged from 648 to $839 \mathrm{mg} \mathrm{g} \mathrm{oil}^{-1}$ among treatments in Exp. A and from 518 to $731 \mathrm{mg} \mathrm{g}$ oil $^{-1}$ in Exp. B. The tocopherol concentration of the oil in growth chamber experiment (Exp. C) ranged from 1155 to $1323 \mathrm{mg} \mathrm{g} \mathrm{oil}^{-1}$.

$\alpha$-tocopherol represented $96.9 \%, 98.0 \%$ and $98.1 \%$ of the total tocopherol in Exp. A, B and C, respectively. The rest of the tocopherol corresponded to the isomer $\beta$ - tocopherol.

In Exp. $\mathrm{A}, \mathrm{H} 1$ and $\mathrm{H}_{2}$ presented a lower total tocopherol content and $\alpha$-tocopherol content than the control $(p<0.012$, Figure 2). In Exp. B, H1 presented a lower total tocopherol and $\alpha$-tocopherol contents than the other treatments $(p<0.02$, Figure 2). In both experiments, $\beta$-tocopherol content was not affected by treatments $(p-0.11$, data not shown).

Differences between field experiments were statistically significant for the content of total

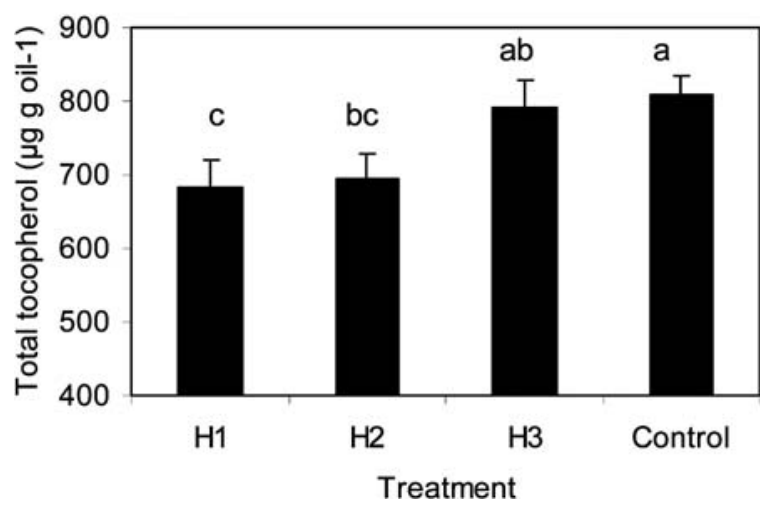

C

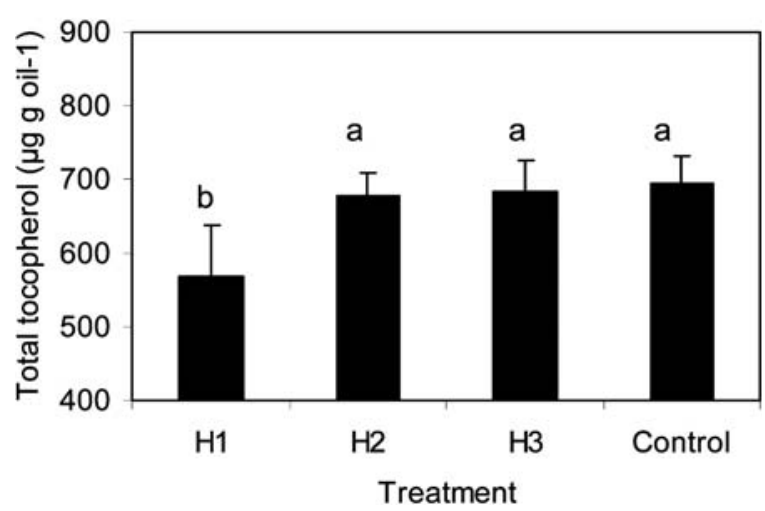

b

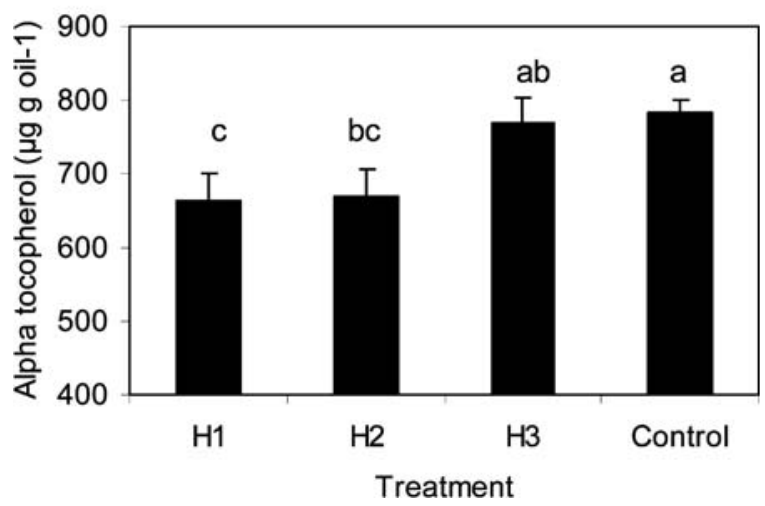

d

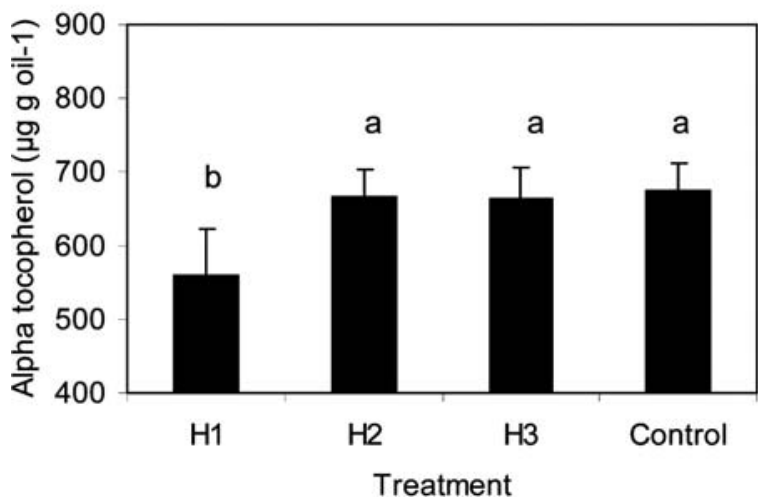

Figure 2

Content of total tocopherol $(a, c)$ and $\alpha$-tocopherol $(b, d)$ of the oil of the traditional hybrid Dekasol 3881 grown in the field under different night temperatures during seed filling from Exp. A and Exp. B. Treatments were a control and three heating periods: from 0 to $200^{\circ} \mathrm{C}$ after flowering $(\mathrm{H} 1)$, from 200 to $400{ }^{\circ} \mathrm{C}$ day after flowering $(\mathrm{H} 2)$ and from 400 to $600{ }^{\circ} \mathrm{C}$ day after flowering (H3). Columns with a same letter do not differ statistically by Tukey $(p<0.05)$. 
tocopherol, $\alpha$-tocopherol and $\beta$-tocopherol $(p<$ 0.0006). The mean tocopherol content in Exp. B was lower than in Exp. A $(662.9 \pm 60.2$ vs $744.4 \pm$ $66.2 \mu \mathrm{g} \mathrm{g} \mathrm{oil}{ }^{-1}$ for total tocopherol, $648.4 \pm 56.2 \mathrm{vs}$ $721.3 \pm 63.9 \mu \mathrm{g} \mathrm{goil}^{-1}$ for a tocopherol and $14.5 \pm$ 8.1 vs $22.9 \pm 6.2 \mu \mathrm{mg} \mathrm{g}$ oil $^{-1}$ for $\beta$ tocopherol). These differences in tocopherol content between sowing dates could be due to the higher temperature registered during Exp $B$.

In Exp. C, no differences in the total tocopherol, $\alpha$ - and $\beta$ - tocopherol concentrations were observed for plants exposed to different day/night temperature and a similar daily mean temperature $(p>0.43$, Table 3). According to these results, night temperature does not affect the tocopherol concentration in the oil.

Mean oil weight per seed ranged from 18 to 37 $\mathrm{mg}$ oil seed ${ }^{-1}$ and total tocopherol content ranged from 518 to $839 \mathrm{mg} \mathrm{g}$ oil $^{-1}$ among treatments and field experiments. The higher total tocopherol concentration in Exp. C (1155 to $1323 \mathrm{mg} \mathrm{g} \mathrm{oil}^{-1}$ ) corresponded to a lower oil weight per seed (7.4 to $12.5 \mathrm{mg} \mathrm{oil} \mathrm{seed}^{-1}$ ) respect to field experiments.

Table 3

Content of $\alpha-, \beta$ - and total tocopherol ( $\mu \mathrm{g} \mathrm{g} \mathrm{oil}{ }^{-1}$ ) for the traditional hybrid Dekasol 3881 for plants grown under different day-night temperatures during seed filling. Data correspond to Exp. C.

\begin{tabular}{cccc}
\hline \multirow{2}{*}{$\begin{array}{c}\text { Day-night } \\
\text { temperature }\end{array}$} & \multicolumn{3}{c}{ Tocopherol content $\left(\boldsymbol{\mu g ~ \text { oil } ^ { - } \mathbf { 1 } )}\right.$} \\
\cline { 2 - 4 } & $\boldsymbol{\alpha}-$ & $\boldsymbol{\beta}-$ & Total \\
\hline $28-20^{\circ} \mathrm{C}$ & $1218 \pm 122^{*}$ & $21 \pm 3$ & $1239 \pm 118$ \\
$25-23^{\circ} \mathrm{C}$ & $1181^{* *}$ & 28 & 1209 \\
$20-28^{\circ} \mathrm{C}$ & $1228 \pm 38$ & $22 \pm 6$ & $1250 \pm 33$ \\
\hline
\end{tabular}

"Standard deviation.

** This treatment was only done in the first repetition so the standard deviation was not calculated

a

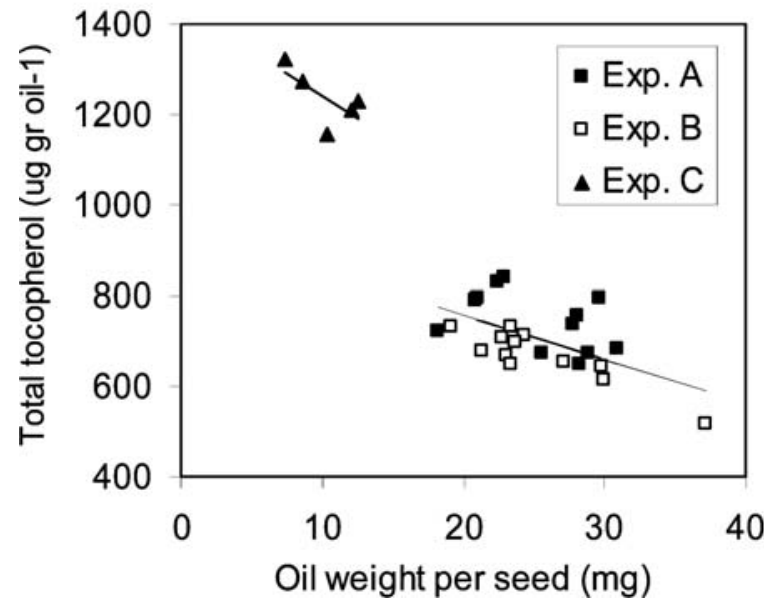

In the field, a negative lineal relationship between total tocopherol content and oil weight per seed was observed for each sowing date $\left(r^{2}=0.55, p=\right.$ 0.0061 and $r^{2}=0.80, p<0.0001$ for Exp. $A$ and Exp. B, respectively). The slopes of both relationships and the intercepts were not statistically different $(p>0.05)$. A single relationship accounted for $33 \%$ of the variability in total tocopherol content of both field experiments of this hybrid $(p=0.0034)$. In Exp. C, the higher tocopherol concentration corresponded to a lower oil weight per seed, respect to the field experiments (Figure 3a).

Total tocopherol and $\alpha$-tocopherol content were highly positively related $\left(p-0.0001, r^{2}-0.99\right)$. A negative lineal relationship was observed between $\alpha$-tocopherol content and oil weight per seed $\left(r^{2}=\right.$ $0.31, p=0.0056$ ) among treatments and field experiments. The relationship between $\alpha$ tocopherol content ( $\mu \mathrm{g}$ tocopherol $\mathrm{g} \mathrm{oil}^{-1}$ ) and oil weight per seed was similar to that described between total tocopherol content and oil weight per seed (data not shown).

The relationships between total tocopherol content $\left(\mu \mathrm{g} \mathrm{g} \mathrm{oil}{ }^{-1}\right)$ and oil concentration (\%) or oil yield per plant ( $\mathrm{g}$ oil plant ${ }^{-1}$ ) were not statistically significant $(p>0.41$ and $p>0.17$, respectively). The relationship between oil tocopherol content and weight per seed was statistically significant $\left(r^{2}=\right.$ $0.32, p=0.0048$ ). However, this relationship was weaker than the relationship between total tocopherol content and oil weight per seed.

In field experiments, increasing night temperature reduced tocopherol concentration (15\% in Exp. A and $B)$ but increased oil weight per seed $(5 \%$, Exp. A) or oil weight per seed (30\%) and tocopherol per seed (14\%, Exp. B). In Exp. C, where no variations in tocopherol concentration among treatments were observed, temperature treatments increased both, oil weight per seed and tocopherol

\section{b}

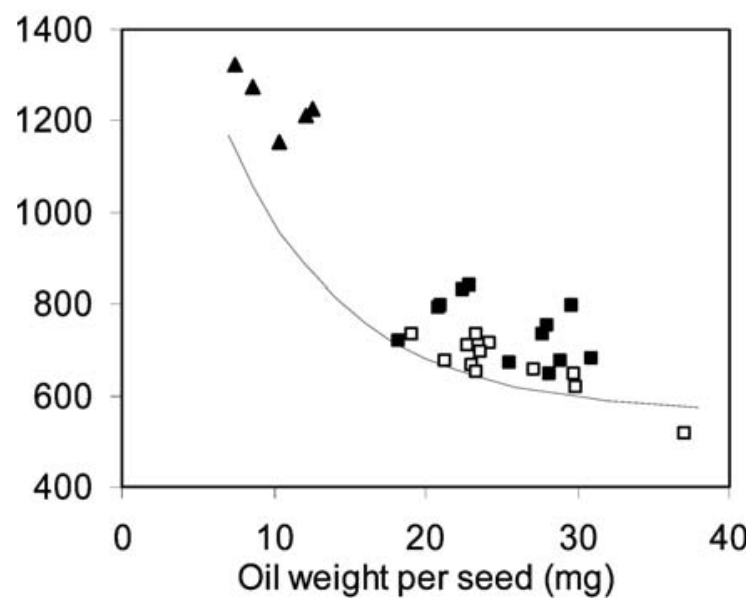

Figure 3

Relationship between oil total tocopherol concentration $\left(\mu \mathrm{g} \mathrm{g} \mathrm{oil}{ }^{-1}\right)$ and oil weight per seed $(\mathrm{mg})$ for the traditional hybrid Dekasol 3881 a) for experimental data and b) experimental data and the function established by Nolasco et al (2004). In graph a lines correspond to the adjusted function of data for field or growth chamber experiments; adjusted functions are $y=-9.496 \mathrm{x}+946.9$ (field exp.) and $y=-20.421 x+1446.0$ (growth chamber exp.). In graph $b$ the line represents the function established by Nolasco et al (2004). 
per seed (Table 4). As oil weight per seed was more increased than tocopherol per seed (for example, $30 \%$ vs $13 \%$, Exp. B).

\section{Relationship between oil tocopherol content and linoleic acid percentage}

The ratio between oil tocopherol content/linoleic acid percentages varied between 1.0 and 3.6 among treatments and experiments (A, B and $C)$. This variation was mainly due to changes in the amount of tocopherols (518-1323 $\left.\mathrm{gg} \mathrm{g} \mathrm{oil}^{-1}, \mathrm{r}^{2}=0.85\right)$, via changes in the amount of oil weight per seed, rather than in the linoleic acid $\left(36.9-69.7 \%, r^{2}=0.61\right)$.

\section{DISCUSSION}

The range of total tocopherol content in the oil found in this work was wide $\left(518-1323 \mu \mathrm{g} \mathrm{g} \mathrm{oil}{ }^{-1}\right)$. It is similar to that reported by Nolasco et al (507$1203 \mathrm{mg} \mathrm{g} \mathrm{oil}{ }^{-1}$, Nolasco et al., 2004), but longer than the reported by other authors $(570-953 \mathrm{mg} \mathrm{g}$ oil $^{-1}$, Kandil et al., 1990; Cole et al., 1998; Purdy 1986; Dorrell and Vick 1997). Higher concentrations in this work were lower than those reported by Velasco et al., (2002, $\left.1872 \mu \mathrm{g} \mathrm{g} \mathrm{oil}{ }^{-1}\right)$. In all experiment, $\alpha$-tocopherol represented the higher proportion of total tocopherol (>96.4\%). The rest of the tocopherols corresponded to the isomer $\beta$ tocopherol. These agree with most of the reports that show that the isomer $\alpha$-tocopherol appears in a higher proportion than $\beta-, \gamma-$, and $\delta$ - tocopherol in traditional sunflower oil (Nagao and Yamazaki, 1983; Nolasco et al., 2004; Lehninger, 1991).

A higher night temperature early during seed filling decreased total tocopherol content and $\alpha$ tocopherol content in land grown plants in both field experiments. These results help to identify the period during which tocopherol content is most sensitive to temperature $\left(0-400{ }^{\circ} \mathrm{C}\right.$ day after flowering). Previous research about the effect of temperature on the tocopherol content in sunflower (i.e. Beringer and Saxena 1968) has been developed by growing plants under the same

Table 4

Oil weight per seed $(\mathrm{mg})$ and tocopherol per seed $(\mu \mathrm{g})$ for the traditional hybrid Dekasol 3881 for plants grown under different day-night temperatures during seed filling. Data correspond to Exp. C.

\begin{tabular}{ccc}
\hline $\begin{array}{c}\text { Day-night } \\
\text { temperature }\end{array}$ & $\begin{array}{c}\text { Oil weight } \\
\text { per seed }(\mathbf{m g})\end{array}$ & $\begin{array}{c}\text { Tocopherol } \\
\text { per seed }(\boldsymbol{\mu g})\end{array}$ \\
\hline $28-20^{\circ} \mathrm{C}$ & $8.0 \pm 0.8^{*} \mathrm{a}$ & $10.4 \pm 0.8 \mathrm{a}$ \\
$25-23^{\circ} \mathrm{C}$ & $10.4^{* *} \mathrm{ab}$ & $12.0 \mathrm{ab}$ \\
$20-28^{\circ} \mathrm{C}$ & $12.3 \pm 0.3 \mathrm{~b}$ & $15.0 \pm 0.5 \mathrm{~b}$ \\
\hline
\end{tabular}

"Standard deviation.

** This treatment was only done in the first repetition so the standard deviation was not calculated. For each variable, means followed by the same letter are not significantly different (Tukey, $p<0.05$ ). temperature during the whole seed period. Our results show that crops exposed to lower temperatures early during seed filling produces higher tocopherol content in the oil. This knowledge could be a useful tool to improve crop management so as to obtain a higher oil quality. Because of differences in total tocopherol concentration between treatments and both field experiments, our results suggest that choosing the optimal sowing date represent an important practice for this purpose, similarly to that described for yield (Andrade, 1995), oil concentration (Aguirrezábal, et al., 2003) and fatty acid composition (Izquierdo et al., 2002).

Night temperature effects on crop yield and quality had received a high attention during recent years because many studies about climate variability indicate a higher increase of minimum (night) temperature through the years than mean or maximum temperatures (Luxmoore et al., 1997; Alward et al., 1999). Our results suggest that such increase has probably lowered the oil total tocopherol content in recent years as increasing night temperature in the field early during filling consistently decreased oil tocopherol content in both experiments. However, the night temperatures increase during seed filling in field experiment originated a correlative increase in daily average temperature. No differences in the total tocopherol, $\alpha$ - and $\beta$ - tocopherol concentrations were observed for plants exposed to different day/night temperature and a similar daily mean temperature in the growth chamber. According to these results, night temperature does not directly affect the tocopherol concentration in the oil suggesting that the effect of temperature on tocopherol content observed in the field could be mediated by the correlative increase in daily mean temperature.

The synthesis pathways of oil and tocopherol are independent (Bramley et al., 2000; Lehninger, 1991) so, changes in environmental conditions could affect differently both syntheses. Increasing night temperature could affect both synthesis but oil weight per seed was relatively more increased than tocopherol per seed in our experiments. Changes in oil weight per seed accounted for most of effects of temperature on tocopherol contents, similar to that reported by Nolasco et al. (2004) for intercepted solar radiation. Moreover, oil weight per seed accounted for changes in tocopherol content between field and controlled condition experiment. Our results indicate that temperature could affect tocopherol concentration, directly, by affecting its synthesis, and indirectly by affecting the oil weight per seed. In all the experiments, this last factor was a strong determinant of the tocopherol concentration in the oil. Any crop management producing variations in oil weight per seed, even by variations in its components weight per seed or seed oil concentration, could also indirectly affect the tocopherol concentration in the oil.

Temperature could indirectly affect the tocopherol content by affecting the oil accumulated per seed. 
High tocopherol content in the oil could be obtained when the amount of oil accumulated per seed is low. This fact could occur with small seeds (i.e. with high plant density or when the growing conditions during seed filling are suboptimal). Chimenti et al. (2001) observed reductions in the final seed weight when temperature was increased. As high temperatures also reduce the duration of the critical period for oil concentration (Aguirrezábal et al., 2003), it could be expected that the higher the temperature the lower the oil weight per seed since both, weight per seed and oil concentration are reduced.

A close relationship between total tocopherol content and the oil weight per seed in sunflower was found in agree with results from Nolasco et al., (2004). The total tocopherol contents estimated by the function established by these authors were lower than the tocopherol contents observed in our experiments but they followed a similar trend for the given range of oil weight per seed Although the relationship of these authors is curvilinear for a range between 8 and $33 \mathrm{mg}$ oil/seed, it tends to be linear for the range of oil weight per seed obtained in the field or in the growth chambers separately.

Oils from all the experiments and treatments presented tocopherol/linoleic acid ratio higher than 0.6 , the ratio suggested by the American Heart Association (2001). This ratio varied between 1.0 and 3.6 among treatments and experiments. This range is slightly higher than that reported by Nagao and Yamazaki (1983) for oils of different hybrids grown under different temperatures during seed filling (0.67-2.67). This variation was mainly due to changes in the amount of tocopherols, via changes in the oil weight per seed, rather than in the linoleic acid. Temperature changed the acid ratio in our experiments. However, this variation is lower than the observed among hybrid types (e. g. between traditional and high oleic hybrids, Mascioli, unpublished). So, traditional oils produced under different temperature conditions (planting locations, sowing dates) would have at seed harvest an enough good quality for human consumption as this ratio is not markedly affected by temperature. However, when the rate of destruction of antioxidants during industry processing is high, oils with higher tocopherol / linoleic ratio must been required. In this case, crop management practices increasing oil tocopherol content must be applied in order to obtain high quality sunflower oil.

\section{ACKNOWLEDGEMENTS}

This study was developed in an interinstitutional agreement between Facultad de Ciencias Agrarias (Universidad Nacional de Mar del Plata), and Facultad de Ingeniería (Universidad Nacional del Centro de la Provincia de Buenos Aires). This investigation was supported by Universidad Nacional de Mar del Plata, Universidad Nacional de Centro de la Provincia de Buenos Aires, Instituto Nacional de Tecnología Agropecuaria, Morgan
Mycogen S.A., Nidera, S.A. and Aceitera General Deheza S.A. Luis Aguirrezábal is a member of the Consejo Nacional de Investigaciones Científicas y Técnicas (CONICET). Natalia Izquierdo and Silvana Mascioli were fellowships of Consejo Nacional de Investigaciones Científicas y Técnicas (CONICET, Argentina) and Comisión de Investigaciones Científicas de la Provincia de Buenos Aires (CIC, Argentina). Thanks are given to Carmen Mateo (Universidad Nacional del Centro de la Provincia de Buenos Aires) for tocopherol determinations.

\section{REFERENCES}

AOCS. Official and Tentative Methods of the American Oil Chemists'Society. 1998. Fifteen edition. A.O.C.S. Press, Champaing, Illinois.

Aguirrezábal LA, Lavaud Y, Dosio GA, Izquierdo, NG, Andrade FH, Gonzalez LM. 2003. Weight per seed and oil concentration in a sunflower hybrid are accounted for by intercepted solar radiation during a definite period of seed filling. Crop Sci, 43,153-161.

Almonor GO, Fenner GP, Wilson RF. 1998. Temperature effects on tocopherol composition in soybean with genetically improved oil quality. J Am Oil Chem Soc, 75, 591-596.

Alward RD, Detling JK, Milchunas DG. 1999. Grassland Vegetation Changes and Nocturnal Global Warming. Science 238, 229-231.

American Heart Association, 2001. AHA scientific statement: summary of the scientific conference on dietary fatty acids and cardiovascular health. $J$ Nutr, 131,1322-1326.

Andrade FH. 1995. Analysis of growth and yield of maize, sunflower and soybean growth at Balcarce, Argentina. Field Crops Res, 41,1-12.

Andrade F, Echeverría H, González N, Uhart S. 2000. Requerimientos de nutrientes minerales in Bases para el manejo del maíz, el girasol y la soja. Andrade F, Sadras V. editors. 443pp.

Beringer H, Saxena NP. 1968. Einflub der temperatur auf den tocopherolghalt von in somenfetten. $Z$ Pflanzenem Bodenk, 120, 157-167.

Beringer H, Dompert WU. 1976. Fatty acid and tocopherol-pattern in oil seeds. Fette Seifen Anstrichmittel 6, 228-231.

Bramley PM, Elmafda I, Kafatos A., Kelly FJ, Manios Y, Roxborough HE, Schuch W, Sheehy PJA, Wagner KH. 2000. Vitamin E (Review). J Sci Food Agric, 80, 913-938.

Cantagallo JE, Chimenti CA, Hall AJ. 1997. Number of seeds per unit area in sunflower correlates well with a photothermal quotient. Crop Sci, 37, 1780-1786.

Chimenti CA, Hall AJ, López MS. 2001. Embryo-growth rate and duration in sunflower as affected by temperature. Field Crops Res, 69, 81-88.

Cole G, Coughlan S, Frey N., Hazebroek J, Jennings C. 1998. New sunflower and soybean cultivars for novel vegetable oil types. Fett/Lipid 100, 177-181.

Devlin TM. 1992. Textbook of Biochemistry with Clinical Correlations. Third Edition. Wiley-Liss Inc. Publication New York. 1185pp.

Dolde D, Vlahakis C, Hazebroek J. 1999. Tocopherols in breeding lines and effects of planting location, fatty acid composition, and temperature during development. J Am Oil Chem Soc,76, 349-355. 
Dompter VWU, Beringer H. 1976. Einflub von Reifedauer, Temperatur und Sauerstoffversorgung auf die Bildung von ungesattigten Fettsuren und Tocopherolen in Sonnenblumenfruchten. Z Pflanzenern Bodenk Heft, 2, 157-167.

Dorrell DG and Vick BA.. 1997. Properties and processing of oilseed sunflower in Sunflower Technology and Production. Editor: Schneider, A.A. ASA, CSSA y SSSA, Madison, Wisconsin, USA. pp. 709-746.

Dosio GAA, Aguirrezábal LAN, Andrade FH, Pereyra VR. 2000. Solar radiation intercepted during seed filling and oil production in two sunflower hybrids. Crop Sci, 40, 1637-1640.

Eitenmiller RR.1997. Vitamine E content of fats and oilsnutritional implications. Food Tech, 51, 78-81.

Farizo CL, Pereyra VR, Cardinali F, Orioli G. 1982. Determination of physiological and harvest maturity in sunflower. Proceedings of the Tenth International Sunflower Conference, Surfers Paradise, Australia. pp. 42-44.

Izquierdo NG, Aguirrezábal LAN, Andrade FH, Pereyra VR. 2002. Night temperature affects fatty acid composition in sunflower oil depending on the hybrid and the phenological stage. Field Crops Res, 77, 115126.

Izquierdo NG, Aguirrezábal LAN, Andrade FH, Cantarero M. 2006. Modeling the response of fatty acid composition to temperature in a traditional sunflower hybrid. Agronomy J, 98, 451-461.

Kandil A, Ibrahim F, Marquard R, Taha S. 1990. Response of some quality traits of sunflower seeds and oil to different environments. J Agron Crop Sci, 164, 224-230.

Lehninger AL. 1991. Bioquímica. Ediciones Omega, S.A. Barcelona. 1117 pp.
Luxmoore RJ, Hanson PJ, Beauchamp JJ and Joslin JD. 1997. Passive nightime warming facility for forest ecosystem research. Tree Psysiology 18, 615-623.

Martínez de la Cuesta PJ, Rus Martínez E, Galdeano MC. 1995. Enranciamiento oxidativo de aceites vegetales en presencia de a-tocoferol. Grasas y Aceites 46, 349-353.

Nagao A, Yamazaki M. 1983. Lipid of Sunflower Seeds Produced in Japan. J Am Oil Chem Soc, 60, 1654:1658.

Nolasco S, Aguirrezábal L, Crapiste G. 2004. Tocopherol oil concentration in field-grown sunflower is accounted for by oil weight per seed. J Am Oil Chem Soc, 81, 1045-1051.

Purdy $\mathrm{RH}$. 1986. High oleic sunflower: physical and chemical characteristics. J Am Oil Chem Soc, 63, 1062-1066.

Robertson J A, Morrison WH. 1979. Analysis of Oil Content of Sunflower Seed by Wide-Line NMR. J Am Oil Chem Soc, 56, 961-964.

Schneiter AA, Miller JF. 1981. Description of sunflower growth stages. Crop Sci, 21, 901-903.

Velasco L, Fernández-Martínez JM, García-Ruiz R, Dominguez J. 2002. Genetic and environmental variation for tocopherol content and composition sunflower commercial hybrids. J Agric Sci, 139, 425429.

White PJ, Xing Y. 1997. Antioxidants from Cereals and Legumes in Natural antioxidants. Chemistry, health effects and applications. Editor: Shahidi, F. AOCS Press, Champaign, Illinois, pp. 25-63.

Recibido: 4/8/06 Aceptado: 19/2/07 